\title{
Local Wisdom as a Social Security Instrument for the Poor in North Maluku, Indonesia
}



Komunitas: International Journal of Society and Culture as.v11i1.18241 9 Semarang State University, Indonesia UNNDS JDURNALS

\section{Safrudin Amin ${ }^{1}$, Irfan Ahmad² ${ }^{2}$ Farida Maricar ${ }^{3}$, Safrudin Abdulrahman ${ }^{4}$}

\author{
1,4 Social Anthropology Departement. Universitas Khairun, Ternate, Indonesia \\ 2 History Departement Universitas Khairun, Ternate, Indonesia \\ ${ }^{3}$ English Departement Universitas Khairun, Ternate, Indonesia
}

Received: August 30, 2018; Accepted: March 1, 2018; Published: March 30, 2019

\begin{abstract}
The studies of cultural revitalization, local wisdom, and social security are often separated and seems unconneted. This article aims at connecting these domains through ethnographic research and document analysis of the phenomena in revitalization of local wisdom called bari to strengthen the social security of the poor in North Maluku. Revitalization activies like raising funds from public not from government budget to build hundreds of decent housing for the poor is interesting issue to study. The three main concerns of this article are socio-cultural factors that encourage the birth of this movement, the activities and achievements of these revitalization movements, and the typical characteristics of local wisdom as a result of revitalization that distinguishes it from its original form. The findings presented in this article can contribute to academic discourse in the domains of local wisdom, cultural revitalization, and social security. The more important of this finding is to construct arguments about the existence of a bridge between local wisdom, revitalization, and social security.
\end{abstract}

\section{Keywords}

local wisdom; social securities; poverty; barifola; republic basedu.

\section{INTRODUCTION}

In North Maluku since 2010s, some groups have set up ethnic and non-ethnic-based community organizations to carry out assistance programs, especially to provide decent housing for the poor. Those community organizations consist of three groups. Firstly, the organization funds and manpower service among Tidore people, North Maluku (known as Ikatan Keluarga Tidore abbreviated to IKA) to build decent houses for urban poor. This activity is called barifola, a cultural concept of Tidore community which means cooperation among community to provide assistance in housing construction. In 2017, barifola has built 190 liveable permanent houses for urban poor (Amin and Karman, 2017). This program continues to this day and interestingly its budget is collected among Tidore community and donors without using local government budget.

Secondly, the Makeang ethnic community incorporated in the association of

\footnotetext{
Corresponding author

Jl. Jusuf Abdulrahman, Universitas Khairun, Gambesi

Ternate, North Maluku, Indonesia 97719

Email

safrudinamin@gmail.com
} 
Makeang Family of North Maluku formed in 2015 also provides assistance to built decent houses for poor families besides giving other social assistance. This activity is called bari um which is a tradition of mutual cooperation to build house for poor people. Like barifola, the source of funding for the bari um comes from donations from Makeang FamilyAssociation without using the budget of local government. In the two years since the establishment of the organization, they have succeeded in building four permanent livable houses in different places.

The third orgnization is non-ethnic-based community called the Republik Basedu. Activists from various North Maluku ethnic backgrounds initiates and organize this group. This group that has motto "turn crying into smile" initially focused on providing basic food packages and cash for the poor and victims of natural disasters. Then at the end of 2016 to 2018 they expanded the program to construction of decent houses for poor families in several areas in North Maluku. The program has succeeded to build seven houses for the poor and all the budgets were obtained from members of Republik Basedu (RB) as well as individuals outside this group.

With the limitations of the country's social programs to reach all citizens, the emergence of civilian philanthropic organizations that take the initiative to help alleviate poverty is an interesting issue to study. Civil initiatives in informal social securities of the three groups above are closely relevant to the conditions of poverty in the North Maluku. Although the annual percentage of the poor population in this region continues to decline (from $13.23 \%$ in 2005 to $11.97 \%$ in 2007 , and again to $6.41 \%$ in 2016), the number of the poor is still quite

large. According to the Statistics Center of North Maluku Province, in September 2016 when the poor were $6.41 \%$ the number of poor people was still 76.40 thousand people. This number increased by around 1.72 thousand people compared to the number of the poor in March of the same year (Rahman, Malut Post, January, 26 2017). The fact that the civil organizations such as bari- fola, bari um, and republik basedu prioritize their social assistance programs more in urban areas is also in line with the reality that poverty rates in urban areas are increasing, whereas rural poverty has declined in the above period.

The interesting point found from the investigation toward the above philanthropic groups is the effort to revitalize the informal social securities based on local wisdom (culture and Islam) to reduce the burden of poverty without involving the formal social security system of the country. This study gives a major attention to the issue of local wisdom revitalization by the civil groups to support the social security of the poor in North Maluku initiated and run by local philanthropic groups.

Although the term social security comes from European countries, in practice all communities have social security mechanisms to help community members in facing socio-economic difficulties. From the view point of state, social security is a public assistance program to overcome difficulties related to health, unemployment, elderly, and other social vulnerabilities. From view point of society, social security, as interpreted by Nooteboom (2003: p.33) is "all ways in which individual people, households, and their community protect livelihoods and are socially protected against shocks and stresses that threaten its continuity and stability".

The term social security, explained by Tang (2005, p. 6) can refer to social phenomena in several levels which consist of values, ideals, ideologies, and goals of wisdom; at the institutional level it provides assistance for those who need; and at the practical level it is real action conducted by groups or individuals. The similar viewpoint is also proposed by de Bruijn (200o, p. 47) who states that the mechanism of social security is social and institutional relations in society that provides protection and guarantees minimum subsistence to its community as what is understood by the community. This is all embedded in culture.

The above concept of social security is considered as traditional or informal social 
securities, while the social securities managed by the government are often seen as formal social securities. If formal social security is seen as a reflection of values, norms, and institutions in society that can give positive contribution to the goodness of the society, informal social securities are part of the community's local wisdom dealing with the insecurity of its citizens. The concept of local wisdom is often described as a asset of local culture that is able to strengthen social relation among citizens, encourage togetherness, and reduce risk (Haba, 2007).

Many studies have been carried out on local wisdom focusing on the contribution of local wisdom to harmonious relations between human and natural natural environment (Berkes, 1999; Soselisa, 2007; Sumarmi, 2015) and contributions to social harmony among different groups of people (Haba, 2007; Rosdiawan, Hudi, and Shaleh, 2007). Other studies reveal the relationship between local wisdom such as reciprocity values and social norms with social security for the poor. Benda-Beckmann (1996), for example, reveals the important role of traditional social security mechanisms such as zakat in Ambon Muslim communities. John van de Ven discovered a local mechanism to overcome insecurity in community of Kerinci, Sumatra Island (2000). Erwin found the importance role of the family groups called samande in social security in the Minangkabau community (2001). De Bruijn investigated the role of Islam in social security of Fulbe community in Mali (2000), Tang revealed social security of the fisherman families in three regions (2005), and many others.

The problem frequently found in traditional social security studies is that there is a tendency to romanticize the capacity of traditional social securities in handling social problems. Some studies show that the rapid socio-cultural changes have weakened the effectiveness of traditional social securities (Indiyanto, 2001; Koning, 2001; Kutanegara, 2006; Nooteboom, 2003). In some African regions, the reduction of the effectiveness of traditional securities is commonly caused by natural factors such as droughts that cause the security system lose its mate- rial basis to be transferred or exchanged (de Bruijn, 2000; van Dijk, 200o;). In contrast to the findings that reveal the weakening of local wisdom which traditionally form the foundation of informal social security in civil society, other studies reveal the strength of traditional social security practices in society (Benda-Beckmann, 1989; Benda-Beckmann, 1996).

The above studies illustrates that although there are different conclusions about local wisdom manifested in traditional social securities and the conditions of their binding capacity in society, the studies do not discuss the phenomena of social securities as a result of revitalization of local wisdom which has previously been weakened in community. In North Maluku, traditional institutions and values of local wisdom supporting social security reappear using traditional names such as barifola and bari-um or a mixture of local and non-local names such as republik basedu are issues. These, however, do not attract much scholarly attention. Several studies have been carried out, especially about barifola (Amin and Karman, 2017; Samuda, 2016), but they have not revealed the sociocultural changes that encourage revitalization and typical characteristics of the local wisdom as a result of revitalization that distinguishes it from its original form. Because the previous studies have not brought to light the Republik basedu movement, this study aims to reveal the activities of revitalization and the results achieved by both Barifola and Republik Basedu.

Referring to the ignorance of several important aspects that have not been presented in previous studies, through ethnographic methods for fieldwork and document analysis, this article discusses three main points, namely the socio-cultural development that encourages the revitalization, the revitalization activities and its achievemnets carried out by barifola and republic of basedu groups, and the characteristics of local wisdom as a result of the revitalization that distinguishes it from its original form.

This article will show the important of 
local value called bari, which inspired various traditional social security in North Maluku. Although the values of bari manifest in many socio-cultural contexts, the focus of this article is only on the revitalization of bari values (the acculturation of local and Islamic values) in building houses for poor people. The civil groups involving actively in the revitalization and become main concern of this article are Tidore ethnic-based groups called barifola and the group which is not based on one ethnic group called Republik Basedu.

\section{DISCUSSION}

To discuss the three points this question, this article begins by briefly discussing sociocultural changes in local communities and the emergence of groups that try to revitalize the local values. After this section, it will discuss the activities of the local wisdom revitalization, as well as the achievements of the movements. Furthermore, the sociocultural characteristics of the local wisdom as a result of revitalization will also be discussed.

\section{The Sociocultural Change and Value of Bari in Building Houses}

In North Maluku, a culture of cooperation to help other people is commonly called bari. Locally, it has several variations in local languages but refer to the same activity of helping other people to ease their burden. In this section we show two local philanthropic groups that try to revive bari value. The first group still uses the basic word bari, called barifola group, and the other group does not use the word bari. The activities of these two groups, however, rely on the spirit of bari values which is the acculturation of Islamic values and local culture.

In daily sociocultural reality, it is frequently found that there is a gap between ideal and actual culture. Some of the values and practices of bari and other values existing in the North Maluku society are still preserved; some have significantly changed and others are no longer practiced.

The example of bari can be seen in community activity to cut forests for farming. In the past, a family could invite villagers for babari (activity to do bari) to help them cut down the trees, especially for trees with large diameter. News of the babari spread through word of mouth among the villagers, and they spontaneously came to help the families who carried out the babari. The obligation of family who were doing $b a$ bari was to provide food for those who come to work during the babari ( $b a$ is the affix which means to do). Today, such practice is rare.

Because bari is reciprocal activity, the family assisted is also obliged to help those who have helped them when they need help. But the practice of bari like this is slowly starting to decline along with the change of people's minds. Most types of work previously carried out through babari begins to be replaced by a wage system where workers must be paid.

Cultural values and practices of bari are widely applicable in various contexts of mutual assistance in community. Traditionally this value is also practiced in mutual cooperation to build houses belong to members of community. In this article, the context of bari is focused on the activity of housing construction.

In the past, Makeang community carried out babari specifically called as bari-um or umbari in language of Makeang (bari means cooperation to help, um means house) to construct houses for the people who need help. In the Tidore community this activity is called barifola (bari means cooperation to help, fola means house). Similarly, this is also applied by about 30 other local ethnics in North Maluku. Now, to build a house, the community relies much on a payment system where they pay carpenters or masons as workers to build houses (Amin and Karman, 2017; Samuda, 2016).

The houses of North Maluku society have actually changed over time. As explained by the informants over the age of 60 , the form of the people's house in North Maluku has transformed from a non-permanent house known as gaba-gaba house that the floor is soil floor, the wall is made of 
gaba (a trunk of sago tree), the roof is made of leaves of sago tree called katu, and the connection between pole and wood used a wooden peg or gomutu rope (a rope from a palm fiber).

At the same time, there was also ancak house, a house with a wall of bamboo (some using wooden board walls), soil floors, wooden poles, and roofs of sagu leaves. The form of Ancak house was also like a stilt house, the ground and the upper floor used a bamboo slice, wooden board or bark of palm tree from various types. It is same as the gaba house which was commonly found the soil floorcoated with bamboo.

The next development was a house type whose foundation has used a mixture of sand, stone and limestone (lime functions as an adhesive) without using iron, while the walls still use bamboo or boards and the roof uses sago leaves. The type of this house is locally called house of stengah leger. A further development of this house is the materials used to make walls of house; the wall is not made of cement but it is made of lime to glue the sands. Inside the wall, there was woven bamboo as a frame to glue a mixture of sand and lime. The house poles still used woods.

When the people of North Maluku became more integrated with the development of housing technology adopted from outside, around the 1980 os in urban areas, especially in Ternate City, the community began to adopt the model of permanent house where the house was made of cement, the pole frames and interiors used iron, concrete walls was made of cement. This kind of development is same as other concrete house in many regions of Indonesia. The local residents also began to learn how to build permanent houses. They also adopted a wage system for masons and carpenters in the construction of houses. This kind of adoption process did not take place simultaneously by all residents of the city.

It should be noted that the above development of the housing technology does not mean that gaba-gaba, ancak, board, or stengah-legger houses were completely abandoned today. The development of hou- sing model is not equally followed by all residents because the developments relatively occurs in the community in a certain period. At present, for example, generally the houses of North Maluku residents are permanent concrete houses, mostly in urban areas or in rural areas that close to the city; however, there are also many people in rural areas who live in house of gaba, ancak, papan, or stenagah leger (Abdulrahman, 2017; Amin, 2017).

The change of housing technology and the adoption of a wage system for building permanent house taken place gradually over the past few decades. It has been an important part of sociocultural change in the community of this region. At the same time, the way of thinking of community members is also increasingly influenced by cost-benefit considerations. The construction workers who can only build houses of gaba, ancak, and papan, are gradually eliminated by the presence of permanent modern house builders coming from outside the region and the emergence of a new generation of local people who actively learn the techniques of constructing a modern permanent house due to market demand.

The rapid changes in housing technology and socio-cultural aspects of society causes the bari values and tradition of bari housing construction such as barifola, barium, babari and other tradions in North Maluku become rarely practiced. Bari tradition which still survives focuse more on wedding and death ceremonies. Commonly, in the construction of houses, bari is no longer widely practiced and mostly replaced by an agreement between homeowners and workers based on the prevailing wage system in the society.

When the value of bari about the tradition of mutual assistance in building a house has been significantly shifted by the technological change and profit-oriented mindset, at the same time there are still many poor people living in inadequate houses like gaba, ancak, and board houses and they need other's help to provide livable houses.

Now, to build a simple, permanent 
and habitable house in urban or rural areas in North Maluku, a family that already has own land for the house must spend at least $\mathrm{Rp} 50$ million. If it is added to the construction workers fee, it can reach to 75 million. Unfortunatey, not everyone has that much saving, especially those who are poor. Therefore, Sofyan Daud, one of the figures in the barifola program, says that there are still many families who still live in uninhabitable homes.

At present, as far as what can be observed in Ternate, the busiest and most developed city in North Maluku, some residents still live the gaba or ancak houses. Those residents mostly become the main target of the barifola philanthropic and the Republik basedu movements in North Maluku.

Realizing the conditions of cultural tradition such as barifola and bari-um have been replaced by another system so that they are no longer working well, middle and upper classes of urban society, especially those who are living in Ternate, initiated movements to revitalize the local wisdom which reflecting values of local culture and Islam to help the marginalized people who still live in uninhabitable homes. The movement was established to revitalize the value of barifola and republic basedu, the two phenomena of social security which become the focus of this study. Daniel P. Strouthes stated: "when conditions change and people feel that their culture no longer serves them ideally in their new circumstances, it often happens that a leader with an idea for cultural revitalization appears (2008, p. 426).

\section{The Revitalization of Bari Values and Traditions: A Case of Barifola}

The fact of sociocultural change swept Tidorenese taking places in Tidore and Ternate shows that this community increansingly abandon the traditional barifola which was traditionally part of the cultural system of Tidore community. Moreover, there is a fact that some Tidore people could not afford to build decent houses in Ternate. Therefore the figures of Tidore people especially Burhan Abdurrahman supported by young figure such as Sofyan Daud has initiated to revitalize the tradition of barifola among the Tidore community who lived in Ternate.

Barifola cannot be separated from the association of Tidore family, known as Ikatan Keluarga Tidore (IKT). This communal organization aims at providing a savings and loan program for Tidore community who live in Ternate in order to improve their economic life. This program, however, did not work well. At a meeting conducted in 2007 , the IKT chairman at that time, Pak. Bur, proposed to change the program with a new program called as barifola. The proposal was based on the awareness that many community who are IKT members still live in inadequete houses. All participants of the meeting supported the idea and proposed pak Bur as the chairman of the barifola program. This program was intended to build decent homes for Tidore community who still live in poverty.

An IKT activist said that all the people attended the meeting agreed to the idea of forming barifola because many Tidore residents in Ternate are poor and live in unlivable houses. The name of barifola is intended to revitalize the old barifola cultureof Tidore community in building houses. Pak Bur began to apply this idea by building the first house using his own money. From March 2007 to August 2009 Barifola has provided 16 units of permanent houses suitable for the poor of Ternate. Until December 2012, the barifola has built 109 decent housing units for the poor.

The success of this program was published by local mass media and spread through word of mouth quikly. This achievement increases public trust to Tidore family association and barifola programs. This increases support in the form of donations and labor to the program. Public support is important because building a barifola house unit requires high cost, which is around Rp. 50 million while labor cost is free. The labor is run by volunteers of Barifola called "laskar mujahiddin". Besides, the increasing public trust also increases public expectationson tp help the poor.

According to one of the figures behind the barifola program, Sofyan Daud, the ent- 
husiastic public support towards the program is because the idea of barifola is not a political program for personal interest but it is a charity program based on Islamic teachings. He argues that Islam commands Muslims to help others who need helps, therefore barifola runs the order. Some other informants also have the same opinions.

Fund-raising support for this program is also from people of Tidore who live in Java, Sulawesi, Papua and other areas outside North Maluku. One of the informants says that beside irregular donors, there are 98 permanent donors with monthly donation of Rp.250.ooo. Thus, the barifola program received donations around Rp. 24.5 million every month if these permanent donors keep donating money monthly. The assistance is also from the people outside Tidore ethnic group including Muslim-Chinese businessmen who owned several stores in Ternate city.

To decide the recipient of housing assistance, Barifola send a survey team that works secretly to know more about the prospective beneficiaries. The results of the survey will be discussed in internal meeting to ensure the eligibility of beneficiaries. The recipient criteria are related to income, marital status, age, and etc. Normally the recipients of barifola housing assistance are those who live in inadequate house, have income of less than Rp. 500 thousand per month, single parent, elderly, do not have other relatives who can support their economic life, and have legal ownership of the land that will be used tp build barifola houses.

The size of barifola houses is about 7x10 square meters and has the same house model because it uses one single reference of house design. Similarly, the paint colors of the houses are same everywhere. The beneficiaries of house assistance are also given household furniture in the form of a dining table set, a sofa set, two spring bed mattresses, and two wardrobes. One of the recipients says that the amount of the furniture is around Rp. 16 million.

In addition to barifola which is seen as elaboration of Islamic teaching to help the poor, the Islamic symbol in this program is also reflected from the name given by Pak Bur to the volunteer team who work on the construction of barifola houses. These voluntary workers are called "laskar mujahidin", an islamic term commonly used for referring to fighters of Islam. Most people who are willing to be "laskar mujahidin" are from lower class. Pak Bur and other Tidore figures usually describe this voluntary group as "the poor help the poor". The members of laskar mujahidin seem to like the label. They often repeat it during the interviews.

The laskar mujahidin is led by a worker who masters the technique of the barifola housing construction. The members also participate in every house construction both in Ternate, a city where they live, and other disctrics in North Maluku even has to cross the ocean. They claim that they participate in the program voluntarily because they believed it is a kind of activity to obey God's order to help others. Usually, during doing their jobs, their family is given $15 \mathrm{~kg}$ of rice, 2 liters of sugar, and some money to buy dayly needs. That amount is certainly insufficient, so the volunteer action is more appropriately seen as a sincere choice to help others. Pak Udin, one of the members of laskar mujahidin from the Makean ethnic group, says that "we cannot help the poor by donation so we help them by being workers on that barifola house construction".

Pak Udin believed that sincerity will be rewarded by the God. He says Allah SWT has promised to repay good deeds to kindness. One day, beyond his expectation, the Barifola team came to deliver building materials including sand and stones and put them in front of his huthouse. Pak Udin's wife said that on that day Pak Udin was not at home. She did not expect the sand and stone were intended build her house. She then asked the truck driver and some people who were carrying the building material, "who order the sand and stones?" They answered "this is assistance from barifola team to build your house". Immediately she cried in tears, grateful to God. she did not expect at all that she and her family would get a decent house.

Pak Udin's wife said that before her 
marriage she and her parents lived in a very poor house with deficient conditions, and this condition did not change after marrying Pak Udin. Now she unexpectedly found a house she had been dreaming of for a long time. She was so deeply touced when she was telling the story and she cried, not because she regretted the past conditions but was grateful for the gifts she has got at this time. Her husband who often works as a member of the laskar mujahidin for barifola, does not expect that he would get a barifola house. The similar stories are also expressed by other Barifola beneficiaries

The achievements of the barifola program are quite impressive. From 2007 to 2018 the barifola movement has built 190 livable permanent houses for the poor. Among them, 168 units were built in Ternate and the 22 units outside Ternate (Amin and Karman, 2007). One of the highlights is that the initial goal of barifola program was to help the Tidore ethnic community who were unable to build their own decent homes. Lately barifola program has also reached to poor communities outside of the Tidore ethnic group, including ethnic immigrants from outside of North Maluku. As founf by Amin and Karman (2017), from 168 houses built in Ternate City, only $79 \%$ or 133 units are for Tidore people, $21 \%$ or 33 units are given to non-Tidore people. Another interesting point is that such achievements is not funded by the local government budget (APBD) but rather funded through public contributions and voluntary labor from community.

\section{The Revitalization of Bari Value: The Case of the Republik Basedu.}

Bari value has various aplications in social context. In the context of house building, Tidorese call it barifola as explained above, while Makeanese call bari um. Outside the context of housing construction, bari values are traditionally practiced in the context of helping the member of community when they carry out an activity which needs support from others. Bari is the general concept, while every local ethnicity in North Maluku has its own vocabulary, both those who con- tinue to use the basic word bariadded their own ethnic language and those who use their own local language without the word bari (Amin, 2017)

Because of the varied local variations, some people of the urban middle class who come from different ethnic backgrounds decided to organize themselves in a philanthropic movement call their group as Republik Basedu (RB). They do not use local ethnic specific term. They prefer that neutral name. In local language of Ternate, the name Republik Basedu literally means republic of joking. It is said republic of joking because it resembles a republic since the group consists of the president of the group, vice president, minister of finance, Coordinating Minister for People's Welfare, minister of transportation, State Minister for Cooperation, Small and Medium Enterprises, and then followed by governors, mayors and regents. It is like a republic but only a joke republic, not a real one.

Actually the idea of the need to organize the rich society to help the poor has been thought by Muhammad Adam, the president of the Republik Basedu. The idea emerged when he was still the head of the social rehabilitation division, Social Service of North Maluku Province. When carried out his duties, he found that many poor people needed help and the state was not able to guarantee their welfare.

In 2012, leaving his position at the social service office, he began to share his ideas through friendships on Facebook. This effort received positive responses from his facebook friends. Several people, then, gathered to discuss the idea including Muhammad Adam, Hekmi Umar Muksin, Basir Pelo Pesi, Nasir Lewelema, Hidayat Solimongo, Ratna (Ci Ratna), Hermayesti Abd. Rachman, Hi.RustamKonoras, Buhari (Bucek), Fitra Waliudu, and many more.

In connection to the urgency of the emergence of this group, Muhammad Adam said that although the program of local governments and non-govermental organization such as Tidore's Barifola have attempted to help the poor such as giving basic foods, providing building materials to 
house construction, it does not mean that they could not participate on the practice of social work to help poor people. He then confirms, "Every person and social institution must take a role ... it is our responsibility to share with other people who have financial problem in building house".

The people who joined the meeting agreed to create a group on social media to share and expand ideas to work together to help the poor. When the Gamalama mountain erupted in 2015, the netizens who joined in facebook group called Fofoki, the previous name of Republik basedu, gathered voluntary donation of money and distributed aid to refugees affected by the eruption. On 27 November 2016 they distributed assistance to 63 heads of families of former lepers. On the same date they changed the name on Facebook from the fofoki to the Republik Baseduc. They began to invite nitizen to join the Republic of Basedu group and at the same time invited them to jointly support the social assistance to the poor.

The Republik Basedu is a media that accommodates and bridges donations coming from those who care about the suffering of the poor to the recipients. They invite the netizens to donate. The program is a kind of charity taught by Islam and in accordance with the culture of North Maluku to help each other. Muhammad Adam, the president of the Republik Basedu, mentions "the bari culture need to be preserved and revived". At other times, he also explains this activityis as an effort to accumulate amal, a charity based on Islamic teaching.

This group is not a formal organization. Therefore it does not have a notary deed. One of the informants says that they only use this group as a media of connecting people (silaturrahmi) and carrying out the mission to help the poor. To maintain solidity and connections among them, the members of Republik basedu organize monthly social gathering namely arisan. During the gathering, they also discuss various programs and collect funds for an aid program. Although it has been agreed that RB is not a formal organization but this group has a clear mission of building togetherness and helping others.

Besides providing basic food, medical equipment, household furniture, and books, the Republik Basedu (RB) also expands the assistance to housing construction for the poor. Until 2018, the Republi basedu has established seven liveable housing units in several different areas in North Maluku. The president of the RB restated that the cultural and religious values were the foundation of doing their assistance program. He said

Every ethnic in North Maluku has a tradition of mutual assistance such as bari, barifola, leleyan, makayaklo, and many others. This tradision is important capital. What we should do is to promote, facilitate, and distribute whatever the donors want to donate. Moreover religion (Islam) teaches us to help one another. Based on this principle, we invite people to share each other, even though the construction of the house takes a lot of time, energy and money, we will not stop this activity.

The way to promote fundraising usually starts with pictures and other initial information about the suffering condition of the poor family posted in the facebook group of Republik Basedu. Then the members of the group discuss about the condition on facebook. If in the discussion many people want to help, the oraganizers of RB conduct a survey to ensure the feasibility of prospective beneficiaries. If it is deemed appropriate, the attempts to persuade the netizen to donate will be made and it is followed by online fundraising in the group.

Here is an example of one of the posts on July 25, 2017,

"Nenek Ijah, a call for grandma ijah $(76$ years old) lives in a hut. She used to work as a laundry worker, but because of her old age, now she only works as a farm keeper. She relies on the producs of farm for her daily meals and takes a bath in the house of local resident. So give our symphaty and sense of humanity by fundraising for her. For those who want to donate, contact to Ratna Na, Fitra Waliulu, and Ija Pattimura.

The post also displayed a picture of the nenek Jijah sitting under a tree and her hut 
house that looked indeed uninhabitable. The post got 73 nitizen's likes and 19 comments. On February 3, 2017 there was a post from Muhammad Adam about developement of housing construction and the proposal of financial assistance. The report was written as follows:

Today, the process of building a house for the poor elderly has reached roof installation, and hopefully it run smoothly. For your information we plan to hand over the house give house on 18 February and [at the same time] addition, we will provide assistance to other poor elderly in the form of food packages for 18 elderly and mattresses and cabinets for 6 elderly. We still need funds for the plans. If any members [of RB] have more money, let's spread smile by donating some by calling Hermayesti's 0822xxx... and transferring to her bank account with number 15000xxx. We as administrators will always be loyal to distribute your sadaqah (donation) to the poor. Thank you. President of RB.

It has been posted on facebook two pictures of houses being worked on the roof and photos of two elderlies. The nitizens joining the group of $\mathrm{RB}$ then responded to those pictures, 83 liked the post, 12 gave comments, and 1 times shared. The post on October 11, 2017 post, Muhammad Adam invited $\mathrm{RB}$ members to attend the hand over of house assistance to Nenek Sehat, an elderly woman, held on October 13, 2017. He thanked to the donors because their contribution was very valuable to Nenek Sehat

Every donation is always posted in the RB's facebook group, as well as the amount of donation so the netizens can see, read and comment on the posting. Likewise, the delivery of assistance is also posted on facebook with various relevant informations. This accountable system makes people to trust $\mathrm{RB}$ in delivering sadaqah, infaq, and other contributions for the poor.

\section{Characteristics of Bari Resulted from Revitalization}

Geertz writes that humans create their symbols (culture) and they are trapped in the symbols that they have created. He also asserts that the symbols are transmitted through inheritance (1973). In Geertz's conception of culture, humans are seen as objects and culture is a subject that traps and regulates humans. Culture is a blue print for human thoughts and actions. This conceptual tool, however, cannot explain why people can get out of the symbolic trap and then try to recreate their culture in order to be more relevant to the current situation and challenges.

The perspective that treats culture as a blue print is not fully able to explain the phenomenon of revitalization. In a revitalization, the relation of culture and humans as the actors of their own culture are more complex and dynamics. In this relations, humans are actually cannot be trapped by the culture they inherited from previous generation. In revitalization, humans are subjects that modify the cultures as an object of their actions. Keesing explains this phenomenon as externalization of culture (Linnekin, 1990). This is a process where culture becomes something out from human, it is thought, discussed, and modified in a reflective manner (Linnekin, 1990, p. 150).

In fact, to revitalize a culture, people should get out, objectify, and modify their culture. Therefore, there is active intervention on the part of human that makes the culture relevant to the present or the current demands. The characteristics of culture resulted from the revitalization, therefore, do not fully resemble the original practiced by previous generations.

There are some typical characteristics of revitalized local culture or local wisdom. In our case, among them are the central role of the urban educated middle class, who initiates and manages the process of revitalization of bari values and traditions. The public support obtained is precisely a reflection of complementary two-sided interactions, including the ability of middle-class ethnic and non-ethnic elites to use public symbols such as bari, sadakah, infaq, charity, and public thoughts related to these symbols. These symbols are chosen reflexively by members of urban middle class to be able to bridge their ideas with public thought about 
bari which is an acculturation of local values and Islam. The public support relies on their self identification towards the local culture and Islam.

Apart from the success of the urban middle class on reviving the existing local wisdom, there are some differences with the original conditions of local wisdom before being revitalized. Bari in the past was intended for all groups and social classes, where all people come together mechanically (in Durkheim's terms) to help their community, whether they are low, middle or high economic positions. The current practice of revitalization is only intended to help the poor or the lower classes.

In addition, the past practice of bari strongly relies on reciprocity value where the community assisted has the obligation to provide same assistance to those who help with the same quality and frequency. In the practice of bari resulted from revitalization the assisted families are not obliged to repay the helps. The disappearance of reciprocity in the revitalized form of bari is also related to the lack of direct relations between those who give donation and those who were assisted because generally the assistance is collected and distributed by third parties, the middle-class urban-based philanthropy organization like barifola dan Republik Basedu.

The lack of direct contact causes those who help and are being helped not to know each other, and even if they have ever met, the relationship is more impersonal. The people the recipients know and respect are the elites and managers of philanthropic organizations who come to help them. In bari practices developed from the previous socio-cultural systems, the relationship between the giver and the recipient is direct and personal, no one oragnizes their meeting, so this, reciprocity can easily take place.

The absence of reciprocity between the giver and the recipient is not only because of the impersonal nature of their social relations but also the revitalization practice is seen as charity dedicated by middle and upper class to the lower class. Bari in the revitalized form is a top-down vertical relation, different from original bari which emphasis horizontal relations among community members. In this top-down relationship, the lower class who is recipient of the assistance is unable to provide counterassistance to the upper class because of the differences in economic classes and the recipients do not know who the donors.

Ideally the functions of social security carried out in the practice of bari can support and maintain social integration. $B a-$ bari event (activity of carrying out bari) is a collective social event in which each person involved shows his presence as part of a social declaration that he is part of its community. In Turner's term, this event is called as "dominant symbols" which function "to establish unity and continuity in society" because it can support the social integration (Erickson and Murphy, 2018, p. 121). To keep solidarity and integrity, social sanctions is set up to those who are not involved in the collective social event.

In the results of revitalization, the practice of bari is not a collective event anymore. It is a limited social interaction between the elite of philanthropic organizations that give aid to beneficiary families and the beneficeries. In this limited context, the solidarity or new social relations can be built vertically between the recipient and the donor. This specific relationship, although this possibility has not been seen so far, could develop into a form of patronage and other loyalty relations between aid recipients and the elite of aid channeling organization.

It seems that this revitalization has transformed away the bari from its original common features such as communal, rural, personal, reciprocity, and integrated in the sociocultural system of a community, into the sociocultural context of middle-urban groups. This urban group may not be concerned with reciprocity and personal relationships, rather prioritize more on the efficient and effective work which means isolating bari from other implicit aspects in order to be managed professionally. If the character of bari in the rural areas runs in a broader sociocultural context and it is intertwined with a broader sociocultural 
system, the practice of bari resulted from revitalization is isolated from the socio-cultural aspects that support bari. As a result, while the practice of original bari especially in rural areas supports the sociocultural solidarity and integration of a community, the practice of urban-based bari resulted from revitalization has no clear impact on community integration and other socio-cultural aspects.

Apart from the various distortions of the original tradition of bari resulted from revitalization, the revitalization carried out by barifola and Republic of Basedu to sustain the social security of the poor, especially the provision of livable houses, shows a worthy success. Many people have been helped by this effort. Also the the success of these programs increases the belief of society that the revitalization of local wisdom to build a better social world is possible.

\section{CONCLUSION}

This article has discussed three main issues regarding the revitalization of local wisdom to support social security for the poor in North Maluku. Those three issues are the various sociocultural and technological changes that have led to the birth of a cultural revitalization movement, the activities of revitalization and its achievements in the form of housing construction for the poor, and the characteristics of local wisdom resulted from revitalization that are unique and different from the original forms.

The changes of housing technology from non-permanent houses (gaba and ancak) to permanent houses, the change of housing construction system from voluntary assistance (as the concept of bari) to wage system, and and change of people's mindsets from moral economy to rationalized cost-benefits considerations have been widely part of social life in North Maluku. At the same time, there are many poor people who cannot afford to build houses which traditionally should be able to be solved by a bari culture. This condition encourages some of the educated urban middle class to organize themselves and revitalize bari va- lues and traditions to support the social security of the poor, especially to build decent houses for the poor.

The consequences of this cultural revitalization are some of the distinctive characteristics of the original bari tradition cannot be presented in urban-based bari tradition resulted from the revitalization. There are many characteristics that differ original bari from revitalized one. However, revitalization efforts seem very constructive since they are able to prove their benefits to some of the poor families. This revitalization has provided decent houses for hundreds of poor families who were previously only able to live in uninhabitable houses.

The biggest questions for this program is how long this cultural revitalization can sustain? The answer to this question depends on how sincere the middle class urban elite to initiate and manage this cultural revitalization movement. Genuineness can maintain energy to sustain dan develop this activity, spuriousness soon kills this movement. There are two reasons underlying this answer. First, in a highly contestative sociopolitical context in North Maluku, this revitalization movement can be easily directed to gain political and economic benefits for personal or group who manage the organizations behind the revitalization. Second, this movement can only be a part of a lifestyle of the urban middle class who are seeking psychological satisfaction by exploiting the poverty of others through showing that they are savior of the poor.

If the goal is for political advantage, then it can be ascertained that this movement will stop immediately when that goal is achieved or not achieved at all. If this is a lifestyle movement to seek personal psychological satisfaction, it is not different from a trend of popular culture that is growing then immediately fades and subsequently replaced by other popular lifestyles. To date, it has not been seen that this movement is only for the purpose of political and economic benefits or merely the lifestyle of an urban middle class. This study was not intended to investigate those things. It is noted from the study that the society have a 
great hopes on the suistanability of the movement.

\section{REFERENCES}

Abdulrahman, S. (2017). Orang Suboyo di Taliabu. $P u-$ lau Taliabu: Sejarah, Masyarakat, dan Perubahan. Andi Sumar Karman (ed). Program Studi Antropologi Sosial, Fakultas sastra dan Budaya Universitas Khairun: Ternate.

Amin, S. (2017). "Orang Mange di Taliabu”, dalam $\mathrm{Pu}$ lau Taliabu: Sejarah, Masyarakat, dan Perubahan. AndiSumar Karman (ed). Program Studi Antropologi Sosial, Fakultas sastra dan Budaya Universitas Khairun: Ternate.

Amin, S. (2017). Menyikapi Kearifan Lokal: Menggali, Menghargai, dan Mengkritisi , 8(2), pp.137-147.

Amin, S. and Karman, A.S., 2017, October. Houses for The Poor: How Local Culture Supports The Housing for The Urban Poor in Ternate-North Maluku. In Unhas International Conference on Social and Political Science (UICoSP 2017). Atlantis Press.

Benda-Beckmann, K. (1989). Social Security in Comparative perspectives. Antropologi Indonesia, 47, pp.117-122.

Berkes, F. (1999). Sacred Ecology: Traditional Ecological Knowledge and Resource Management. Braun-Brumfield: London.

deBruijn, M. (200o). The Sahelian Crisis and the Poor: The Role of Islam in Social Security among Fulbe Pastoralists, Central Mali. Coping with Insecurity: An 'Underall' Oerspective on Social Security in the Third World, Franz von BendaBeckamann, Keebet von Benda-Beckmann dan Hands Marks (eds). Pustaka Pelajardan Focaal Foundation: Yogyakarta.

Erickson, P. A., and Murphy, L. D. (2018). Sejarah Teori Antropologi: Penjelasan Komprehensif. Edisi 5. Prenadamedia Grup: Jakarta.

Erwin. (2001). "Dinamika Pengorganisasian Jaminan Sosial dalam Keluarga pada Masyarakat Petani di Pedesaan Minangkabau: Studi Kasus Masyarakat Desa Sungai Tanang, Kabupaten Agam", in Sumber Daya Alam dan Jaminan Sosial, Benda-Beckmann F. Von, K. Von, dan Juliette Koning (eds), 2001, Pustaka Pelajar: Yogyakarta.

Geertz, C. (1973). The Interpretation of Cultures. Bacic Books, Inc: New York.

Haba, J. (2007). Penutup: Analisis SWOT Kearifan Lokal dalam Resolusi Konflik. Revitalisasi Kearifanlokal, Alpha Amirrachman (ed). ICIP Europen Comission: Jakarta.

Handler, R. (1984). On Sociocultural Discontinuity: Nationalism and Cultural Objectification in Quebec. Current Anthropology, 25. pp: 55-71.

Indiyanto, A. (2001). Strategi Sekuritas Pangan Rumah Tangga: Kasus Pedusunan Kedungmiri, Yogyakarta. Sumber Daya Alam dan Jaminan Sosial. Franz von Benda-Beckamann, Keebet von
Benda-Beckmann and Julliette Koning (eds). PustakaPelajar: Yogyakarta.

Koning, J. (2001). Akses Terhadap Tanah dan Air di PedesaanJawa: Peranan Sumberdaya Alam dalam Jaminan Ekonomi dan Sosial. Sumber Daya Alam dan Jaminan Sosial. Pustaka Pelajar: Yogyakarta.

Kutanegara, P. M. (2006). Solidaritas Sosial, Masihkah efektif?: Jaminan Sosial dan Perubahan di Indonesia. Esai-esai Antropologi: Teori, Metodologi dan Etnografi. HeddyShri AhimsaPutra (ed.). Kepel Press: Yogyakarta.

Linnekin, J. (1990). The Politics of Culture in the Pacific. Cultural Identity and Ethnicity in the Pacific. Jocelyn Linnekin dan Lin Poyer (eds), University of Hawaii Press: Honolulu.

Nooteboom, G., 2003. A Matter of Style: Social Security and Livelihood in Upland East Java, Indonesia. [Sl: sn].

Rahman, B. F. (2017). Mendalami Data Kemiskinan Maluku Utara. Malut Post, 26 January.

Rosdiawan, R., Hudi, Z. and Shaleh Ibrahim M., (2007). Merajut Perdamaian di Kalimantan Barat. Revitalisasi Kearifan lokal, Alpha Amirrachman (ed). ICIP - Europen Comission; Jakarta.

Samuda, S. (2016). Bari Fola Sebagai Modal Sosial dan Instrumentasi Masyarakat Tangguh Bencana. Jurnal Penelitian Humaniora, 21(2), pp.109-118.

Soselisa, H. (2007). Sasi Laut di Maluku: Pemilikan Komunal dan Hak-hak Komunitas dalam Manajemen Sumberdaya Kelautan. Sumber Daya Alam dan Jaminan Sosial. Franz von Benda-Beckamann, Keebet von Benda-Beckmann and JullietteKoning (eds). PustakaPelajar: Yogyakarta.

Strouthes, D. P. (2008). Native Americans. International Encyclopedia of the Social Sciences, 2nd edition.William A. Darity Jr. (ed). Macmillan: USA. Detroit.

Sumarmi, S., 2015. Local Wisdom of Osing People in Conserving Water Resources. Komunitas: International Journal of Indonesian Society and Culture, 7(1), pp.43-51.

Tang, M. (2005). Kajian Sekuritas Sosial Bagi Keluarga Nelayan Miskin di Kota Makassar Provinsi Sulawesi Selatan, Kota Bau-bau Provinsi Sulawesi Tenggara, dan Kota Ternate Provinsi Maluku Utara. Report. Departemen Sosial RI dan Lembaga Penelitian Universitas Hasanuddin Makassar.

Van de Ven, J. (2000). Members Only: Time-sharing Rice Fields and Food Security in a Sumatran Valley. Coping with Insecurity: An 'Underall' Oerspective on Social Security in the Third World, Franz von Benda-Beckamann, Keebet von Benda-Beckmann dan Hands Marks (eds). Pustaka Pelajar dan Focaal Foundation: Yogyakarta.

Van Dijk, H. (200o). Livestock Transfers and Social Security in Fulbe Society in the Hayre, Central Mali. Coping with Insecurity: An "Under- 
all" Perspective on Social Security in the Third World. Franz von Benda-Beckmann, Keebet von Benda-Beckmann, and Hands Marks (eds). Pustaka Pelajar and Focaal Foundation: Yogyakarta.

von Benda-Beckmann, K., 1996. The Practice of Care: Social Security in Moslem Ambonese Society. in D. Mearnsdan C. Healey (ed.), Remaking Maluku: Social Transformation in Eastern Indonesia (121-39). Darwin: Northern Territory University. 
46 Safrudin Amin, et al, Local Wisdom as a Social Security Instrument for the Poor in North Maluku... 